Note

\title{
Identifying a Culture of Excellence
}

Bouke van Gorp ${ }^{1}$, Nelleke de Jong ${ }^{2}$, Elanor Kamans ${ }^{3}$, Svenja Buttner ${ }^{4}$

1. Utrecht University, Faculty of Geosciences, Department of Human Geography and Planning, The Netherlands, b.vangorp@uu.nl

2. University of Twente / Hanze University of Applied Sciences, Research Center Talent Development in Higher Education and Society, The Netherlands, n.a.de.jong@pl.hanze.nl

3. Hanze University of Applied Sciences, Research Center Talent Development in Higher Education and Society, The Netherlands, e.kamans@pl.hanze.nl

4. Hanze University of Applied Sciences, Research Center Talent Development in Higher Education and Society, The Netherlands, s.a.buttner@pl.hanze.nl

Received: 30 January 2017; Accepted: 24 February 2017; Published: 12 April 2017

Keywords: Culture of Excellence, Ambitious school culture, Higher Education

\section{Introduction}

Over the last decades, the attention paid to excellent student performances in higher education has increased in many European countries, including traditionally egalitarian societies such as The Netherlands. By means of selective study programs, termed honors programs, gifted students who are motivated to do more than the regular program offers, are enabled to excel (Wolfensberger, 2015). The growing number of honors programs offered at institutes for Higher Education (ITS, ROA \& CHEPS, 2015; Wolfensberger, 2015), the emerging literature on characteristics of honors students and the effects of honors programs on their development (Banis-den Hartog, 2016; Kool, 2016; Kolster et al. 2016; Scager et al. 2012; Scager et al. 2013), and the foundation of the European Honors Council stand testimony to this growing attention for excellence.

The Sirius Program (a government initiative) proved important in fostering honors education in The Netherlands. It aimed not only at meeting the needs of talented students who are able and willing to excel, but also at creating an ambitious school culture in Higher Education in general (Janssen \& Gramberg, 2014). By establishing honors programs, so it was expected, a focus on excellent student performances would devolve to the entire institute, creating a 'Culture of Excellence': a school culture in which excellence is considered both norm and normal. Although the concept 'Culture of Excellence' has become common parlance in Dutch policy documents, an unambiguous conceptualization of it lacks to date. To explore whether honors programs have the assumed transformative power, a clear definition of the concept is asked for. 


\section{Culture of Excellence}

To define the concept of 'Culture of Excellence', the present study started with a broad literature review, which included both policy papers and academic publications on 'school culture' and 'excellence'. We found one study that attempted to measure culture of excellence in Higher Education (Tiesinga \& Wolfensberger, 2014). It focused on the culture within honors programs as measured by attitudes and characteristics of honors students. Based on our extensive literature review, we propose a more encompassing definition.

We define 'Culture of Excellence' as a part of school culture that is created by students and faculty. School culture is something that is not visible and difficult to define, but is manifested in the behavior of people within a school (Pol, 2005). Schein (2010, p. 23) discerns three layers in school culture: artifacts, espoused beliefs and values, and basic assumptions. Hence, a culture of excellence implies that excellence is included in convictions, values, norms, and practices in school. We thus define 'Culture of Excellence' as: "A school culture in which students who want to excel are challenged, allowed and enabled to deliver outstanding performances by using pedagogies geared at outstanding performances". Allowing students to excel implies that there are no repercussions towards ambitious students and that outstanding performances are appreciated and stimulated.

This definition leaves the term 'excellence' undefined. The concept 'excellence' is socially constructed and related to general notions of students, learning and teaching (Dai \& Chen, 2013). Researchers differ on conceptualizations of talent, giftedness and explanations of outstanding performances (Harder et al., 2014; Ambrose, 2010 in: Laine et al., 2016). Authors such as Matthews and Foster (2006), Johnson (2005) and Dai and Chen (2013) introduce paradigms of giftedness.

In line with these overviews we identified four key questions that together mold perspectives on excellence in higher education: Who, What, How, and Why? Who deals with the characteristics of excellent students: is every student able to deliver excellent performances or only a small, selective group of students? What is concerned with the recognition of excellent performances: what characterizes an excellent performance? How refers to pedagogies that empower students to deliver excellent performances. Lastly why deals with the societal relevance of education geared at excellence. Positions differ between neoliberal claims about international competition in the knowledge economy and a focus on individual learning needs (Cross \& Cross, 2005). The answers to these four questions form a perception of excellence in Higher Education, which shape one's attitudes, norms and behaviors.

At the Utrecht Honors Conference (2016) workshop participants were invited to share their ideas about 'Culture of Excellence'. These honors educators mentioned a plethora of ideas that reflect the variety of perceptions on excellence. They talked about talent development "using all talents" and differentiation (who); about critical thinking, creativity, innovation and making each other great (what); about learning community, self-regulation and culture of learning (how). They also mentioned that a definition of excellence should always relate to the goals and terms a program has set. 


\section{To conclude}

This research note addressed the assumed transformative power of honors education: investing in an honors program is said to create a Culture of Excellence in the entire educational institution: an ambitious school culture where excellent performances are norm and normal. Following the longstanding debates on excellence in education, we feel that this transformative power can only take place if faculty and students have insight in their beliefs about excellence. If (opposing) views on excellence are not made explicit, the new focus on excellent student performances which is created by honors programs may leave both faculty and students disappointed: students who see good grades for tests as a mark of excellence will struggle with 'out of the box' assignments, and teachers who expect good students to excel in all subjects may complain about the amount of instruction these students require. Having insight in the (diverging) views on excellence may help members of a school culture (students and faculty) to create common language on who or what is excellent and define shared, attainable goals for the future to stimulate a Culture of Excellence in their institution.

\section{Acknowledgements}

This presentation was prepared by members of the Exchange project, a NRO-funded (grant 405-15-603) research on transfer and cultural change though excellence education. The authors would like to thank the workshop participants for their participation and useful comments.

\section{References}

Banis - den Hartog, J. (2016). X-factor for innovation: Identifying future excellent professionals (dissertation Universiteit Twente).

Cross, J.R., \& Cross, T.L. (2005). Social dominance, moral politics, and gifted education. Roeper Review, 28(1), 21-29.

Dai, D.Y., \& Chen, F. (2013). Three paradigms of gifted education in search of conceptual clarity in research and practice. Gifted Child Quarterly, 57(3), 151-168.

Harder, B., Vialle, W., \& Ziegler, A. (2014). Conceptions of giftedness and expertise put to the empirical test. High Ability Studies, 25(2), 83-120.

ITS, ROA, \& CHEPS (2015). Het beste uit studenten. Onderzoek naar de werking van het Sirius Programma om excellentie in het hoger onderwijs te bevorderen. Nijmegen: ITS, Radboud Universiteit Nijmegen.

Janssen, M., \& Gramberg, E. (2014). Manifest voor het excellentieonderwijs van de toekomst. Amsterdam: Hogeschool van Amsterdam en Sirius Programma. Retrieved from https://www.siriusprogramma.nl/publicaties/manifest-voor-de-toekomst-van-hetexcellentieonderwijs\#.WE5ExbLhDIU 
Johnson, A. (2005). Caught by our dangling paradigms: How our metaphysical assumptions influence gifted education. The Journal of Secondary Gifted Education, 16(2-3), 67-73.

Kolster, R., Dijk, L. \& Jongbloed, B. (2016). Excellence in higher education: Educational preferences of honours students in the Netherlands. CHEPS working paper 01/2016. Enschede: CHEPS.

Kool, A. (2016). Excellence in higher education: Students' personal qualities and the effects of undergraduate honors programs. (dissertation Utrecht University).

Laine, S., Kuusisto, E., \& Tirri, K. (2016). Finnish teachers' conceptions of giftedness. Journal for the Education of the Gifted, 39(2), 151-167.

Matthews, D.J., \& Foster, J.F. (2006). Mystery to mastery: Shifting paradigms in gifted education. Roeper Review, 28(2), 64-69.

Pol, M., Hlouskova, L., Novotny, P., Vaclavikova, E. \& Zounek, J. (2005). School culture as an object of research. Online Submission, New Educational Review, 5(1), 147-165.

Scager, K., Akkerman, S.F., Keesen, F., Mainhard, M.T., Pilot, A. \& Wubbels, T. (2012). Do honors students have more potential for excellence in their professional lives? Higher Education, 64(1), 19-39.

Scager, K., Akkerman, S.F., Pilot, A. \& Wubbels, T. (2013). How to persuade honors students to go the extra mile: Creating a challenging learning environment. High Ability Studies, 24(2), 115-134.

Schein, E.H. (2010). Organizational culture and leadership. New York: John Wiley \& Sons.

Tiesinga, L. \& Wolfensberger, M. (2014). De cultuur van honoursstudenten en de mogelijke invloed op de reguliere studiecultuur. Tijdschrift Voor Hoger Onderwijs, 4(2), 5-20.

Wolfensberger, M.V.C. (2015). Talent development in European higher education. Honors Programs in the Benelux, Nordic and German-Speaking Countries. Heidelberg: Springer. 